\title{
Influence of home on study habits of secondary school students in Kolo-Creek development centre of Bayelsa State, Nigeria
}

\author{
Hamilton-Ekeke, Joy-Telu ${ }^{1,}$, Ekima Ayebaemi Frank-Oputu \\ ${ }^{1}$ Department of Teacher Education, Faculty of Education, Niger Delta University, Wilberforce Island, Bayelsa State, Nigeria \\ ${ }^{2}$ Department of Teacher Education, Niger Delta University, Wilberforce Island, Bayelsa State, Nigeria
}

\section{Email address:}

joytelu@yahoo.com (Hamilton-Ekeke, Joy-Telu)

\section{To cite this article:}

Hamilton-Ekeke, Joy-Telu; Ekima Ayebaemi Frank-Oputu. Influence of Home on Study Habits of Secondary School Students in KoloCreek Development Centre of Bayelsa State, Nigeria. International Journal of Secondary Education. Vol. 1, No. 5, 2013 , pp. $39-44$. doi: $10.11648 /$ j.ijsedu.20130105.15

\begin{abstract}
This study investigates the home and its influence on students' study habits. Simple random sampling technique was used to obtain 200 out of 660 SS2 students in Kolo-Creek Development-Centre of Bayelsa State. Four research questions were posited, data were collected using Student Study Habit Questionnaire, (SSHQ) which was analyzed using percentages, mean and standard deviation. It was found that $134(67 \%)$ of the respondents agreed that motivation from parents like provision of the recommended books influences them to read at home. Also some independent variables like parent income, education, living abode influence their wards' study habits. The study went further to investigate some practical steps that parent could take in order to improve their wards' study habits: which include making home a miniature of schools (that is homes should be conducive for reading), drawing up reading time table for their children and encouraging them to follow through every evening as well as devote their time to teach their children, although, parents level of education could be a set back to the latter. Finally, it was recommended that parents should be more responsive to their children's education by providing learning facilities as well as conducive and motivating learning atmosphere at home.
\end{abstract}

Keywords: Study Habits, Secondary School Students, Home, Academic Ability

\section{Introduction}

The environment in which a child lives is one of the critical factors influencing his/her study habit and ultimately contributes to the progress of the child in school. There are lots of home-related factors that have negative as well as positive consequences on students' academic performance and ability. Educators and psychologists believe that the home provides the basic ingredient that propels the child for wholesome development [1-3]. When children grow up to school age, the home environment still play significant role in the children's academic achievement. As a result, educators and psychologist have always channeled their interest on home factors that have high impact on secondary school students' achievement and its relationship to the home environment. For instance adolescents see home as a means of their emotional problems, parent's attitude like restriction, over protection, harassment, physical abuse, not providing enough money for the child; all attributes to emotional distress among adolescents which consequently result to individual behavioural attitudes towards school work or activities [4]. Reference [1] said most homes lack sound moral environment, like teachers; parents ought to live exemplary life style for their children and wards to emulate. What legacy will a father have to give or leave for his children if he leaves home every day and return home drunk? How can a father or mother who does not keep matrimonial chastity advice his or her children as they continue to fight each day in the house? All these influence the study habit of children at home. Again [1] reiterated that the rate of child abuse today in our society is causing a lot of concern to critical minded people.

Under-aged children are always seen along the streets and corners of towns and villages selling one item or the other; students are no longer allowed to prepare themselves for schools the next day after school; they are engaged at home that they cannot do their assignments that are given to them in school. Lack of parental care is also another 
factor in the home environment which can affect student study habit. Good parents provide their children with the things they actually need for their school work. Actually, it involves more than just paying the bills, such parents help their children with take home assignment and lots of encouragements in all aspects of their school career, the children in turn develop proper aims and goals in life. They provide the children with the home environment that is conducive; they cultivate in their children the study habit of learning by inspecting their children's notes when they come back from school. They praise them and encourage them when they perform well at school; thus motivate the children to work hard. They also make sure that they have enough textbooks to assist them in their studies. Children may also need help with their work and part of the parent duty should be to be involved and not to saddle them with much household work which will not allow them to do their take home assignment. Reference [2] found out that the location of the home; learning facilities and what he called 'study-psychological-warmth' of the home enhance study habit. In a nutshell, parents can enhance students study habit by offering a stimulating and academic rich environment by providing the child with enough reading and writing materials which will facilitates learning.

The main objective of this study therefore was to determine the relationship between home environment and students' study habit. The variables investigated in this study are: students' study habits as the dependent variable whilst parental educational background; parental works status and how conducive is the home environment to student study habit are the independent variables. Based on the objectives of the study the following research questions were posited for the study:

1. To what extent does parent level of education influences student study habit?

2. Does parent residence influence student study habit?

3. Does parent socio-economic status affect student study habit?

4. What steps can parent take to enable children to form good reading habit?

\section{Review of Related Literature}

Environment is important to the physical, mental, emotional and intellectual development of a child. Home environment refers to the total home circumstance surrounding an individual or groups of individuals. In this work, it will involve a combination of the external physical home conditions such as parent's social status; parent's abode as well as income that affects their wards study habits. Study habit is operationally defined as a dedicated scheduled and un-interrupted time to apply one's self to the task of learning. The way a child is trained at home influences his or her study habit. Whatever the home life is, it can reflect on the child's school work, as a child who is cherished and well cared for, usually study well. On the other hand, children who lack parental affection; love and tender care find it difficult to form a stable relationship with other children. According to [5], emotional disturbance helps to take away the appetite to study, unhappiness at home, and resentment towards the teacher also causes poor student study habit. Apart from pre-school influence, the home still exert much influence during schooling for example, situation of overcrowding in the home. Reference [5] added that "overcrowded home will deprive one of quietness and privacy. When several children share bed, they may sleep badly and through tiredness will be unable to concentrate on their school work".

Waste of talent is another adverse effect that could emanate from unfavourable home environment. Reference [5] (ibid) put forward that "at an even earlier age (below school age) waste of talent may occur through the effect of adverse home environment or through lack of stimulation in early life. National Teachers Institute (NTI) [6] comments on the effect of home on students that "what happens outside the classroom also affects the learning process'. Obviously, the experience the child gets from the father and mother who are related to him/her should help to advance the work of the school in the home. In another study conducted by [2], it was discovered that eight (8) out of ten (10) students were approved of their achievement, that their parent trusted them, showed them affection, encourage them to do more. The percentage of the students also claimed that they happily accepted their parent standards value and goals. On the other hand, the under achievers were very anxious of parental dissatisfaction with their non-achievement and seem to understand that their parental pressure was very much, in which case, they find it difficult to communicate with their parents. Also on the same study, it was discovered that a child who was born in a broken home is more likely delinquent even when the child is being influenced. When a child is deprived of affection this in turn affects his intellectual development. The absence of the mother or father results in an emotional stress which in turn may affect the student's study habit.

Apart from the independent variables investigated in this study of home environment, there are other extraneous variable that can affect students study habit and these are:

- Motivation: This is a force or drive that directs and sustains human behavior towards a desired goal. Parents who take active interest in their children's performance in school provide necessary encouragements that enable their children to succeed. Students with high level of motivation are very industrious with their school work. Some of them may face hardship, but due to the intense desire to succeed, they move ahead in order to achieve their purpose. According to [7], history has innumerable records of people with average intelligence but whom with sheer determinant effect to succeed, climbed to a greater height.

- Self Concept: This has to do with evaluating oneself. If a student sees himself/herself as one 
who cannot achieved academically, his/her effort of studying will definitely be affected because he/she already has negative thought about himself/herself and negative thought leads to negative result such as students refusing to study. But those students with positive thoughts about themselves try as much as they can to be very studious.

- Ability: According to [8], intellectual endowment plays a vital role in students study habit. In most cases, a child who possesses low intellectual power cannot study effectively and in some cases influence a student study habit. Students who are endowed with high intellectual power, with little effort in their home environment will study well [8]

- Health: It is a well known fact that one who is unhealthy cannot study well, when a person is in good health, he has a stronger drive to learn and work vigorously.

\section{Method}

Kolo-Creek Development Centre is one of the twenty four development centres created from the eight Federal Government recognized and originally approved Local Government Areas in Bayelsa State. The State Government under the leadership of the first Executive Governor, Chief D.S.P. Alameisegha in his wisdom deemed it fit to create more local government areas referred to as Development Centres to meet grass root development, participation and involvement in governance. Kolo-Creek Development Centre consisted of ten secondary schools with a population of 660 senior secondary two students. Twenty students from each of the ten secondary schools were randomly selected to make up the sample for this study - 200 Senior Secondary two (SS2) students of Kolo-Creek Development Centre. The sample size of 200 students aged 14-16 years is approximately $30 \%$ of the total population of the study which is the benchmark for a representative sample size.

This study was a descriptive survey research on the influence of home environment on students study habit. A structured questionnaire designed by the researchers was used in data collection. The questionnaire was a four point Likert scale of Strongly Agreed (SA), Agreed (A), Strongly Disagreed (SD) and Disagreed (D). The questionnaire was the main instrument used for data collection as a result some precautions were taken in designing the questionnaire, these are: that only relevant and straight to the point questions were asked; the questionnaire was also designed in a simple format so that they would be easily understood and answered by the respondents unaided. The face and content validity of the questionnaire was ascertain by presenting them to experts in measurement and evaluation while its reliability was ascertain using test re-test method of administering the questionnaire to a small sample size (thirty SS2 students) not involved in the main sample and the questionnaire re-administered after two weeks to the same students. The two results were then analysed using
Spearman Rank Correlation Coefficient. A coefficient of 0.70 was realized which is within the benchmark of reliable coefficient.

Two hundred copies of the questionnaires were administered personally by both researchers to the 200 respondents across the ten participating secondary schools. The completed 200 questionnaires were retrieved by the researchers. Data were analysed using percentages, mean and standard deviation.

\section{Result}

Analysis of data was done based on the research questions posited for the study. For the purpose of analysis and concise representation of results on tables, the four (4) point Likert scale was collapsed into two points of Agree (A) and Disagree (D). This was done by summing up the responses of Strongly Agreed (SA) with Agreed (A) responses to be the Agreed (A) responses; likewise the Strongly Disagreed (SD) responses were summed up with the Disagreed (D) responses to be the Disagreed responses.

The four schools in Kolo-Creek Development Centre involved in the study are:

Community Secondary School, Kolo

Community Secondary School, Emeyal

Community Secondary School, Otuasega and

Matter Dei High School, Imiringi

Demographic Data of Respondents

Table 1. Respondents Gender

\begin{tabular}{|c|c|c|c|}
\hline \multirow{2}{*}{$\mathbf{S} / \mathbf{N}$} & \multirow{2}{*}{ Name of School } & \multicolumn{2}{|c|}{ Gender } \\
\hline & & Male & Female \\
\hline 1 & C.S.S. Kolo & 24 & 26 \\
\hline 2 & C.S.S., Emeyal & 28 & 22 \\
\hline 3 & C.S.S., Otuasega & 21 & 29 \\
\hline 4 & $\begin{array}{l}\text { M.D.H.S., Imiringi } \\
\text { Total }\end{array}$ & $\begin{array}{c}27 \\
100\end{array}$ & $\begin{array}{c}23 \\
100\end{array}$ \\
\hline
\end{tabular}

From Table 1 above, the study had equal gender participation i.e. out of the 200 respondents that participated in the study, $100(50 \%)$ were male and 100 $(50 \%)$ were female; this shows that both boys and girls percentages are the same $(50 \%)$ but different in the individual sample sizes that make up the study.

Table 2. Total number of students in each school and their arms

\begin{tabular}{clclc}
\hline S/N & Schools & $\begin{array}{c}\text { Number of } \\
\text { Students }\end{array}$ & Class & Arms \\
\hline 1 & Css kolo & $55(27.5 \%)$ & SS II & 2 \\
2 & Css emeyal & $67(33.5 \%)$ & SS II & 1 \\
3 & Css otuasega & $73(36.5 \%)$ & SS II & 1 \\
4 & Mdhs imiringi & $75(37.5 \%)$ & SS II & 2 \\
\hline
\end{tabular}

From Table 2 above, the total number of students in Kolo (SS II) is $55(27.5 \%)$ with two arms, one was randomly selected, also the total number of students in Emeyal (SS II) 
is $67(33.5 \%)$ and all in one arm, in Otuasega a total of 73 $(36.5 \%)$ students were in SS II and all in one arm and in Imringi a total of $75(37.5 \%)$ students were in SS II and in two arms, one was randomly selected. In each of these arms 50 students each were randomly selected to constitute the total sample size of 200 .

Table 3 above shows that 134 (67\%) of the respondents on item one agreed that motivation from parent influences them to read at home, while $66(33 \%)$ of the respondents

Research Question 1: To what extent does parent level of education influence student study habit?

Table 3. Influence of parent's educational level on student's study habit

\begin{tabular}{|c|c|c|c|c|c|c|c|c|}
\hline $\mathbf{S} / \mathbf{N}$ & Questionnaire item & $\mathbf{A}$ & $\%$ & D & $\%$ & $\overline{\mathbf{x}}$ & $\sigma$ & Grand Total \\
\hline 1 & $\begin{array}{l}\text { Motivation from parents influences the student to read at } \\
\text { home. }\end{array}$ & 134 & 67 & 66 & 33 & 50 & 17.97 & 200 \\
\hline 2 & $\begin{array}{l}\text { Student whose parents are degree holder study better at } \\
\text { home }\end{array}$ & 113 & 56.5 & 87 & 43.5 & 50 & 13.07 & 200 \\
\hline 3 & $\begin{array}{l}\text { Student whose parents have secondary school certificate } \\
\text { study better at home }\end{array}$ & 73 & 36.5 & 127 & 63.5 & 50 & 21.97 & 200 \\
\hline 4 & $\begin{array}{l}\text { Student whose parents have first school leaving } \\
\text { certificate study better at home }\end{array}$ & 58 & 29 & 142 & 71 & 50 & 25.09 & 200 \\
\hline 5 & $\begin{array}{l}\text { Children whose parents have no educational } \\
\text { qualification study better at home }\end{array}$ & 54 & 27 & 146 & 73 & 50 & 63.5 & 200 \\
\hline
\end{tabular}

Research Question 2: Does parents` residence (place of abode) influences student study habit?

Table 4. Influence of parent residence on student study habit

\begin{tabular}{|c|c|c|c|c|c|c|c|c|}
\hline SN & Questionnaire item & $\mathbf{A}$ & $\%$ & D & $\%$ & $\overline{\mathbf{x}}$ & $\sigma$ & Grand Total \\
\hline 1. & $\begin{array}{l}\text { Place of living influence students study } \\
\text { habit. }\end{array}$ & 136 & 68 & 64 & 32 & 50 & 18.24 & 200 \\
\hline 2. & $\begin{array}{l}\text { Parents places of living can affect student } \\
\text { study habit }\end{array}$ & 141 & 70.5 & 58 & 29 & 50 & 20.20 & 200 \\
\hline 3. & $\begin{array}{l}\text { Academic ability of students reflects home } \\
\text { background. }\end{array}$ & 114 & 57 & 86 & 43 & 50 & 9.21 & 200 \\
\hline
\end{tabular}

Research Question 3: Do parents' socio economic status affect student study habit?

Table 5. Socio-economic status of parent and student study habit

\begin{tabular}{|c|c|c|c|c|c|c|c|c|}
\hline SN & Questionnaire item & $\mathbf{A}$ & $\%$ & D & $\%$ & $\overline{\mathbf{x}}$ & $\sigma$ & $\begin{array}{c}\text { Grand } \\
\text { Total } \\
\end{array}$ \\
\hline 1 & Income of parents affects student study habit & 135 & 67.5 & 65 & 32.5 & 50 & 17.95 & 200 \\
\hline 2 & $\begin{array}{l}\text { Parent status in society influence student } \\
\text { study habit }\end{array}$ & 139 & 69.5 & 61 & 30.5 & 50 & 20.65 & 200 \\
\hline 3 & $\begin{array}{l}\text { Student from high socio-class home are more } \\
\text { expose to academic upbringing }\end{array}$ & 146 & 73 & 54 & 27 & 50 & 23.85 & 200 \\
\hline
\end{tabular}

Research Question 4: What step can parents take to enable children form good reading habit?

Table 6. Steps parents could take to help their children form good reading habit

\begin{tabular}{|c|c|c|c|c|c|c|c|c|}
\hline SN & Questionnaire item & $\mathbf{A}$ & $\%$ & D & $\%$ & $\overline{\mathbf{x}}$ & $\sigma$ & $\begin{array}{l}\text { Grand } \\
\text { Total }\end{array}$ \\
\hline 1 & $\begin{array}{l}\text { Parent should not provide a conducive } \\
\text { learning place for student at home since they } \\
\text { are available in the school }\end{array}$ & 53 & 26.5 & 147 & 73.5 & 50 & 10.02 & 2000 \\
\hline 2 & $\begin{array}{l}\text { Parent should draw reading time table for their } \\
\text { children and encourage them to follow up } \\
\text { every evening }\end{array}$ & 150 & 75 & 50 & 25 & 50 & 25.67 & 200 \\
\hline 3 & $\begin{array}{l}\text { Parent should devote their time to teach their } \\
\text { children on how to read at home }\end{array}$ & 163 & 81.5 & 37 & 18.5 & 50 & 33.35 & 200 \\
\hline 4 & $\begin{array}{l}\text { Children should not be freely allowed to } \\
\text { watch TV }\end{array}$ & 75 & 37.5 & 125 & 62.5 & 50 & 13.47 & 200 \\
\hline
\end{tabular}

More number of respondents (86) disagreed that academic ability of students reflects home background 
compared to the numbers who disagreed with 'parents' place of living affecting student study habit and also place of living influencing study habit 58 and 64 respectively. From Table 4 above, 136 (68\%) of the respondent agreed that place of living influences student study habit. On the second item, $141(70.5 \%)$ agreed that parents place of living can affect student study habit. On item three, 114 $(57 \%)$ of the respondent agreed that academic ability of the student shows home background.

From Table 5 above, on item one 135 (67.5\%) of the respondents agreed that income of parents affect student study habit, while $65(32.5 \%)$ of the respondent disagreed. On item two, $139(69.5 \%)$ of the respondent agreed that parents status in the society influence student study habit, while $61(30.5 \%)$ of the respondent disagreed on the statement. On item three, $146(73 \%)$ of the respondent agreed that student from high socio-class home are more expose to academic up bringing while 54 (27\%) of the respondent disagreed.

Table 6 reveals that, out of the two-hundred students that participated in the study $53(26.5 \%)$ of the respondent on item one agreed that parent should not provide a conducive learning place for children at home since they are available in the school, while $147(73.5 \%)$ of the respondent disagreed. On item two 150 (75\%) of the respondent agreed that parent should draw reading time table for their children and encourage them to follow up every evening, while 50 $(25 \%)$ of the respondent disagreed. On item three, 163 (18.5\%) of the respondent agreed that parent should devote their time to teach their children on how to read at home, while $37(18.5 \%)$ of the respondent disagreed. On item four, $75(37.5 \%)$ of the respondent agreed that children should not be freely allowed to watch TV, while 125 $(62.5 \%)$ of the respondent disagreed with the statement.

\section{Discussion of Findings}

In this study, attempts have been made to examine some home factors that relates to student study habit. There is the need to enhance student study habit at the secondary school level, as means of preparing them for their academic tasks at the tertiary level. This objective accounts for why there is a need to assess parental background factors and the possible influence on student study habit. The variable examined include, parent education and qualification, parent residence, parent socio-economic status, and the steps which parent can take to enhance their children's reading habit. It was found from the study that children whose parents are degree holders study better at home than children whose parent's educational qualification is school certificate and first school leaving certificate. This finding collaborated with [5]. Reference [5] found out that parent's level of education largely influence study habits of their children. Students whose parent are well educated also enjoy extra attention than those whose parent are not, commonly educated parents guide their children on assignment given to them by their teachers and this cumulate their overall assessment, parents educational level according to [9] stimulates interest in ensuring that their ward or children do well in their educational pursuit, therefore, they are easily counseled based on their foreknowledge of academic demands.

This study also found out that parent's socio-economic status affects students study habit. Reference [9] posited that, the level of industrial development among developing nation of Africa is an off shoot of poor educational standard which is a reflection of the depressed economic circumstance of such nation. In other words, household economic situation may likely affect several activities, including the academic ability of children. It further asserted that the socio-economic status of parent largely determine the ability to under-unite the financial demands of their academic pursuit. What this simply means is that, parent's who cannot pay up their children's fees would have their children driven out of school which will in turn affect their study habit. A buoyant parent provides all study items (books and learning aids) which guarantees the children to be committed to study at all time.

The study also examined parent residence (place of abode) on student study habit. It was also found out that a relationship though not strongly exist between the residential place of parents and student study habit. The different accommodation type and neighbourhood are important factors that encourage studying among students. Reference [10] argued that children who live with their parent in a small accommodation with neighbours often face the challenges of not having serene opportunity to study; students in such neighbourhood are more interested in unpaid fraternity that breeds more of vices than studying. In contrast, [10] has also argued that children with their parents in high brow areas have academic stakes as they are well expose both in terms of learning facilities, and space to undertake their studies. They are properly recreated through the environment to be refreshed for studies. This assertion is in line with the findings of this study.

\section{Conclusion}

From the results of this study, it can then be concluded that the home has a vital role to play in student study habit that will help to revive the falling standard of secondary school education. Parents should know that family is the first unit of a child's socialization unit, this means, there are duties to be perform for the children. Despite the nature of the family background, the family should never neglect its basic responsibilities towards the children. In the various questionnaire items, the respondents have pointed out the important roles that parents need to play like things they can do to help improve their wards study habit such as reading with them and helping out with their homework, if these measures from the findings on this study are put into practice, it will definitely go a long way to restore the rapidly deteriorating study habits amongst secondary school students. 


\section{Recommendations}

Based on the findings of this study, the following are therefore recommended.

1. That parent should develop more positive attitude towards their children education, creating more time for their children to study.

2. Provide more educational facilities, conducive and motivating learning atmosphere at home.

3. They should try and show concern towards their children education by establishing an adequate parent teacher relationships.

\section{References}

[1] S.O. Amale, "Moral values in Nigeria Education Issues Problem and Prospects". Nigeria: Christ David Publishing Company 2000.

[2] J. Spring, "America Education" New York: McGraw Hill Companies Inc, 2002.

[3] J-T Hamilton-Ekeke, J-T, "Home environment and school learning in Nigeria" Nigerian Journal of Education, Health and Technology Research, vol.3 No.1, 2011, pp. 86-93
[4] J-T Hamilton-Ekeke, and B.N Mathew, "Improving school environment to enhance students' learning", Nigerian Journal of Education, Health and Technology Research, vol.2 No.1, 2011, pp. 118-124

[5] R.S Douglas "The Home and the School: A Study of Ability and Attainment in the Primary", London: Hagibeen and Kee Ltd, 1998.

[6] National Teacher Institute, "NCE/DLS Book on Education cycle 2", Kaduna: National Institute Publishing, 1990.

[7] R. Maze, "Parents Push College over Sciences many Times", 62 (42), 24 EBSCO host, 2002.

[8] J. Emeka, "Family Environment and Academic Achievement of some Secondary School Student" Calabar: Umeh Publishing, 2000.

[9] A. Bamisanye and B. Williams, "A Behavioural Study of Children into difference Socio Economic sectors of the City of Ibadan", West Africa Journal of Education vol. 2, 2000, pp. 93-103.

[10] J.O Ogunlade, J.O (2001), "Family Environment and Atonement of some children in Western Nigeria", West Africa Journal of Education, vol. 3, 2001, pp. 15-21 